\title{
Circulating Epithelial Cell
}

National Cancer Institute

\section{Source}

National Cancer Institute. Circulating Epithelial Cell. NCI Thesaurus. Code C122733.

A cell derived from an epithelial membrane that is found in the blood. These cells are associated with epithelial-mesenchymal transition and may be markers for neoplastic diseases. 